\title{
Determination of Photon Conversion Factors Relating Exposure and Dose for Several Extremity Phantom Designs
}

P. L. Roberson

F. N. Eichner

W. D. Reece

September 1986

Prepared for the U.S. Department of Energy under Contract DE-AC06-76RLO 1830

Pacific Northwest Laboratory Operated for the U.S. Department of Energy by Battelle Memorial Institute 


\title{
DISCLAIMER
}

This report was prepared as an account of work sponsored by an agency of the United States Government. Neither the United States Government nor any agency thereof, nor Battelle Memorial Institute, nor any of their employees, makes any warranty, expressed or implied, or assumes any legal liability or responsibility for the accuracy, completeness, or usefulness of any information, apparatus, product, or process disclosed, or represents that its use would not infringe privately owned rights. Reference herein to any specific commercial product, process, or service by trade name, trademark, manufacturer, or otherwise, does not necessarily constitute or imply its endorsement, recommendation, or favoring by the United States Government of any agency thereof, or Battelle Memorial Institute. The views and opinions of authors expressed herein do not necessarly state or reflect those of the United States Government or any agency thereof, or Battelle Memorial Institute.

\author{
PACIFIC NORTHWEST LABORATORY \\ operated by \\ BATTELLE \\ for the \\ UNITED STATES DEPARTMENT OF ENERGY \\ under Contract DE-AC06-76RLO 1830
}

\begin{tabular}{|c|c|}
\hline \multicolumn{2}{|c|}{ Printed in the United States of America } \\
\hline \multirow{2}{*}{\multicolumn{2}{|c|}{$\begin{array}{c}\text { Available from } \\
\text { National Technical Information Service }\end{array}$}} \\
\hline & \\
\hline \multicolumn{2}{|c|}{ United States Department of Commerce } \\
\hline \multicolumn{2}{|c|}{$\begin{array}{c}5285 \text { Port Royal Road } \\
\text { Springfieid, Virginia } 22161\end{array}$} \\
\hline \multirow{2}{*}{\multicolumn{2}{|c|}{$\begin{array}{l}\text { NTIS Price Codes } \\
\text { Microfiche A01 }\end{array}$}} \\
\hline & \\
\hline \multicolumn{2}{|c|}{ Printed Copy } \\
\hline & Price \\
\hline Pages & Codes \\
\hline $001-025$ & $\mathrm{~A} 02$ \\
\hline $026-050$ & $\mathrm{~A} 03$ \\
\hline $051-075$ & $\mathrm{~A} 04$ \\
\hline $076-100$ & A05 \\
\hline 101-125 & $\mathrm{A} 06$ \\
\hline $126-150$ & $\mathrm{~A} 07$ \\
\hline $151-175$ & $\mathrm{~A} 08$ \\
\hline $176-200$ & A09 \\
\hline $201-225$ & A010 \\
\hline $226-250$ & A011 \\
\hline $251-275$ & A012 \\
\hline $276-300$ & A013 \\
\hline
\end{tabular}




\title{
DETERMINATION OF PHOTON CONVERSION FACTORS RELATING EXPOSURE AND DOSE FOR SEVERAL EXTREMITY PHANTOM DESIGNS
}

\author{
P. L. Roberson \\ F. N. Eichner \\ W. D. Reece
}

Septeniver 1986

Prepared for the U.S. Department of Energy under Contract DE-ACO6-76RLO 1830

Pacific Northwest Laboratory

Richland, Washington 99352 
FOREWORD

Accurate, reliable estimates of absorbed dose are essential to the management of each individual radiation worker's exposure. Over the past few years, accreditation and application research programs focused on the accuracy of dosimeters used for external, whole-body measurements with little attention to dosimeters used for extremity measurements. Anticipated changes in basic radiation protection standards are mandating that greater emphas is be placed on extremity measurements. Specifically, promulgation of the proposed revision to the Environmenta?. Protection Agency's "Radiation Protection Guidance to Federal Agencies for Occupational Exposures" would lower the exposure Iimit for extremities from 75 to $50 \mathrm{rem}$, and would require an improved ability to differentiate between penetrating and nonpenetrating exposures. Additionally, the International Commission on Radiological Protection has recommended that the quality factor for neutrons be raised from 10 to 20 , which will then effectively reduce the allowable neutron exposure to the extremities. In view of these developments, the Health Physics Group, Office of Nuclear Safety, is accelerating its efforts in extremity dosimetry development.

In 1982, the Health Physics Society Standards Committee (HPSSC) initiated the draft ANSI P/N13.32, "Standard for the Performance Testing of Extremity Dosimeters." The standard, in part, is expected to consider the results of a study supported by the Department of Energy (DOE) that was intended to provide information on the selection of an appropriate calibration phantom for extremity dosimeters and the need to include exposure-to-dose conversion factors $\left(C_{x}\right)$ for extremity dosimetry. When the HPSSC has completed its effort, DOE plans to evaluate the standard for incorporation into the DOE Laboratory Accreditation Program for Personnel Dosimetry.

Edward J. Vallario

Acting Director

Radiological Controls Division

Office of Nuclear Safety

Department of Energy 


\section{EXECUTIVE SUMMARY}

This report presents the results of measurements of dosimetric properties of simple extremity phantoms suitable for use in extremity dosimeter performance testing. Two sizes of phantoms were used in this study. One size represented the forearm or lower leg and the other size represented the finger or toe. For both phantom sizes, measurements were performed on solid plastic phantoms and on phantoms containing simulated bone material to determine the effect of backscattered radiations from the bone on the surface dose.

Exposure-to-dose conversion factors $\left(c_{x}\right.$ factors) were determined for photon energies ranging from 16 to $1250 \mathrm{keV}$ (average for ${ }^{60} \mathrm{Co}$ ). The effect of the presence of a phantom was also measured for a ${ }^{90} \mathrm{Sr} /{ }^{90} \mathrm{Y}$ source. The ratio of the dose to thin thermotuminescent dosimeters on the surface of the phantoms to the dose to the dosimeters in air was determined using replicate measurements. The measured ratios were multiplied by well-known values to arrive at $C_{x}$ factors.

Significant differences in the measured $C_{x}$ factors were found among the phantoms investigated. The factors for the finger-sized phantoms were uniformly less than for the arm-sized phantoms. The factors for the finger phantoms did not vary significantly between phantoms that had simulated bone inserts and those that did not. The most likely cause of this insensitivity to construction for finger phantoms was the small size of the phantom. Oniy a small phantom backscatter contribution was made to the surface dose (less than $20 \%$ for all energies) and minor variations in this contribution are relatively unimportant. The $C_{x}$ factors for arm phantoms with either bone-equivalent or aluminum inserts were significantly less than factors for solid plastic phantoms over the energy range of 40 to $100 \mathrm{keV}$. This effect was attributed to the preferential absorption of the lower energy backscattered photons in the higher atomic number material of the insert.

Because of the small effect of simulated bone inserts on the $C_{x}$ factor for finger phantoms, we recommend a solid plastic phantom for use in calibration. Oue to the relatively large effect of simulated bone inserts at the middle $x$-ray energies for the arm phantom, a phantom with an insert of higher 
atomic number materiat is recommended. This should result in a closer correspondence between surface dose on the extremity phantom and the extremity of the worker for the same radiation field conditions. The position of the bone-simulating material below the surface of the phantom is more important than its size or its level of bone equivalency. For simplicity, we recommend that a phantom with an aluminum insert be used. The diameter of the insert may vary between 48 and $60 \mathrm{~mm}$ without greatly affecting the $c_{x}$ factors. 


\section{ACKNOWLEDGMENTS}

The authors wish to express their appreciation to C. D. Hooker, R. T. Hogan, V. C. Tews, and C. A. Simonen for assisting in the irradiation and processing of the dosimeters discussed in this report. We thank N. R. Gordon for mixing the bone-equivalent plastic used in some of the phantoms. We also thank the Pacific Northwest Laboratory Graphics Section for drafting support, Craft Services for preparation of the phantoms, M. Cross for word processing, and C. P. Brim and K. Brun for technical editing. 


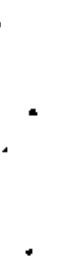


FOREWORD . . . .

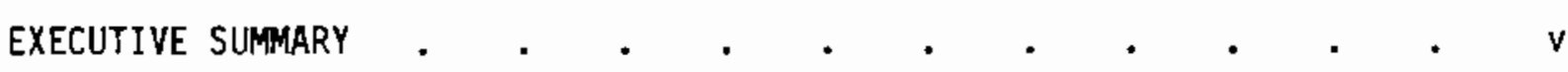

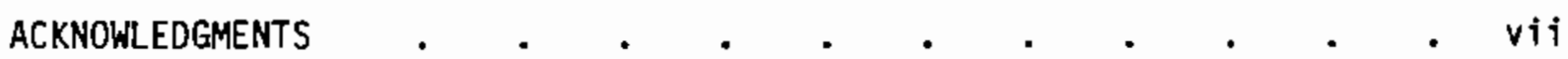
I.O INTRODUCTION

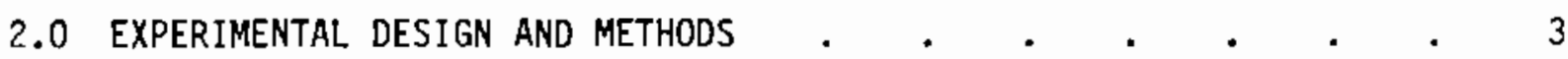

2.1 APPROACH . . . . . . . . . . . . . . . 3

2.2 PHANTOM DESIGN . . . . . . . . . . . . . . . 4

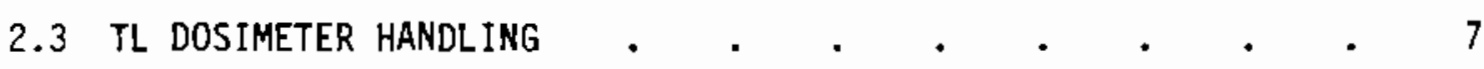

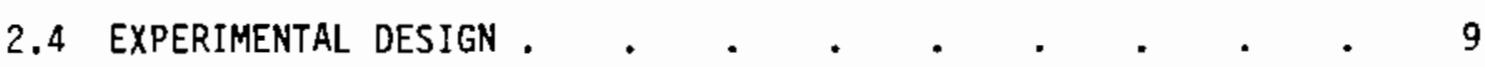

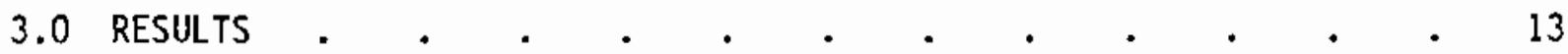

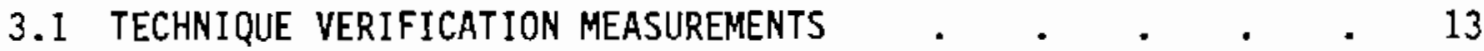

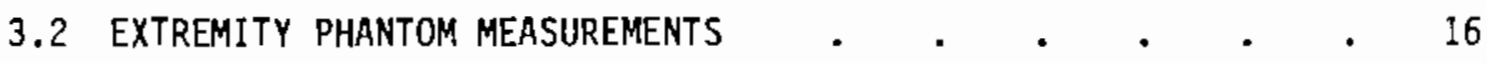

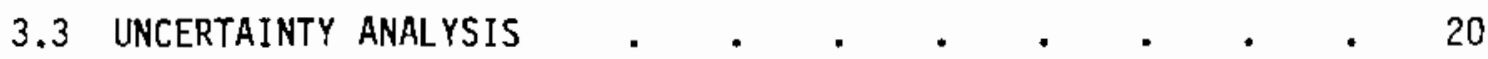

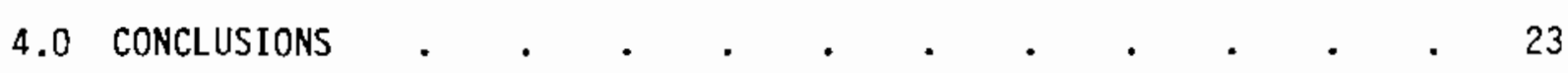

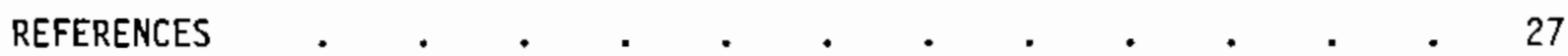
APPENDIX - PROCEDURES FOR USE OF VINTEN THIN TL DOSIMETERS • • • $\quad$ A.1 
FIGURES

3.1 Energy-Dependent Response for the Thin TL Dosimeters . . . 14

3.2 Energy Dependence of the Response Ratios for the On-Phantom-to-In-Air Ratios . . . . . . . . . . 19

4.1 The $C_{y}$ Data with One Standard Deviation Random Uncertainties and Dêrived Smooth Curves . . . . . . . . 25

$\underline{\text { TABLES }}$

2.1 Composition of Bone-Equivalent Plastic Mix SB5 . $\quad$. $\quad$. $\quad$. 6

2.2 Comparison of Properties of Bone, Aluminum, and Muscle . . . . 6

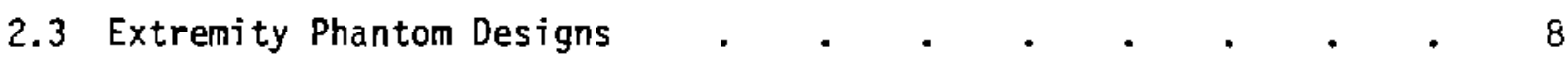

2.4 Irradiation Source Properties . $\quad . \quad$. $\quad . \quad$. $\quad . \quad$. 10

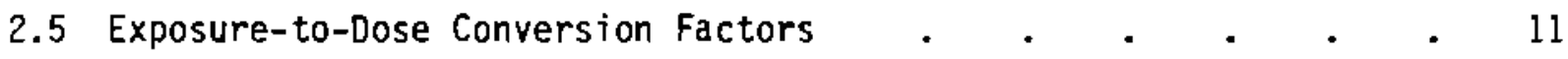

3.1 Energy-Dependent Response of the Thin Dosimeters . . . . . 14

3.2 Comparison of Shallow $C_{x}$ Factors for Body Phantoms $\quad$ • • • $\quad 15$

3.3 Measured On-Phantom-to-In-Air Ratios for Extremity Phantoms . . 17

3.4 Exposure-to-Dose Conversion Factors for Extremity Phantoms . . 20

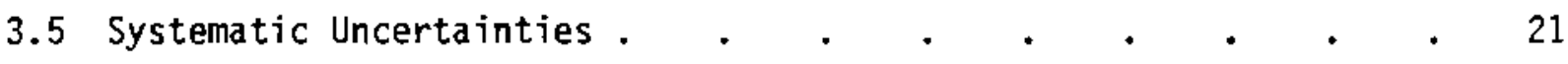

4.1 Exposure-to-Dose Conversion Factors $\quad . \quad$. $\quad . \quad$. $\quad . \quad$. 24 


\subsection{INTRODLCTION}

The response of personnel dosimeters can vary widely in the absence of guidance specifications for their calibration and energy response determinations. The universal use of specified and easily-constructed calibration geometries will provide a conmon means for comparing dosimetry results and striving for improvements. No such guidance exists for specifying calibration geometries and dose for the calibration of extremity dosimeters.

This report describes prototype extremity phantoms and their dose specification factors ( $C_{x}$ factors) used in a study to aid the Health Physics Society Standards Committee to select phantom designs and $C_{x}$ factors for the development of a draft American Nationa 1 Standards Institute (ANSI) standard entitied "Standard for the Performance Testing of Extremity Dosimeters (ANSI P/N13.32)." This study also adds to the avatlable information on the calibration of extremity dosimeters for use by the Department of Energy (DOE).

The approach to defining standard calibration specifications is parallel to that used for the performance testing of personnel body dosimeters in the ANSI Standard N13.11, "Criteria for Testing Personnel Dosimetry Performance" (ANSI 1983). That standard specifies the phantom types; the irradiation geometries; and photon, neutron, and beta energies for the conduct of performance tests.

Even though the calibrations of dosimeters for occupational environments very often differ from those used for the laboratory test, the test calibration represents a reference point for all dosimeters. As refinements in personnel dosimetry are made, a conmon goa 1 will be the improvement of the dose specification for the test irradiations and the improvement of the designs of the personnel dosimeters. These improvements will minimize the difference between the calibrations for the occupational environments and the performance tests. To better achieve this goal, the test specifications should be made as realistic as practicable.

Dose measurements were performed to determine $C_{x}$ factors for a variety of simple extremity phantoms. The phantoms were chosen to represent the forearm or the lower leg, or a finger or toe. The phantoms were constructed of solid 
plastic (polymethyl methacrylate, PMMA) or of a PMMA cylindrical shell with a core of higher atomic number material. Measurements were performed with photon source energies ranging from $16 \mathrm{keV}$ to $1.25 \mathrm{MeV}$ (average) and a ${ }^{90} \mathrm{Sr} /{ }^{90} \mathrm{Y}$ beta source. The measurements will be used to provide approximate $\mathrm{C}_{\mathrm{x}}$ factors for use in calibrating extremity dosimeters on simple phantoms, to estimate the significance of $C_{x}$ factors for extremity dosimetry, and to help the Heaith Physics Society Extremity Standards Committee choose phantom designs. 


\section{D EXPERIMENTAL DESIGN AND METHODS}

Dose at the surface of extremity phantoms was measured for many source energies. The approach used to measure dose and to derive the $C_{x}$ factors is described in Section 2.1. The phantom design and construction is described in Section 2.2. The use of the dosimeters is described in Section 2.3 and the experiment design is described in Section 2.4 .

\subsection{APPROACH}

The measurement of surface dose for an extremity phantom is not easily performed with an instrument. The sensitive volume must be very smati to avoid perturbing the radiation field at the measurement location. Rather than expend a considerable effort performing a measurement using an instrument with a tissue-equivalent response, a simple approach using themoluminescent (TL) dosimeters was chosen. An instrument measurement may have resulted in smaller systematic errors, depending on the level of tissue equivalency that could have been achieved. The precision of the measurements, however, would probably have been worse than was obtained by using the TL dosimeters. The potential problem of systematic errors affecting the TL dosimeter results were minimized by performing repetitive measurements on the extremity phantoms and performing similar measurements on the body phantoms, for which tabulated $C_{x}$ factors are available. The measurement uncertainty analysis is presented in Section 3.3.

The TL dosimeters were selected based on availability, thickness of the sensitive layer, and dosimetric properties. The available TL dosimeter with the thinnest effective depth (quoted as $5 \mathrm{mg} / \mathrm{cm}^{2}$ of LiF) was manufactured by Vinten Instruments Limited (Dutt et a1, 1984). The Vinten dosimeters were tested for dosimetric properties and reproducibility, resulting in a technique to successfully reuse these dosimeters, even though they are designed to be discarded after one use. This procedure is described in Section 2.3 and the appendix. The nomina $5-\mathrm{mg} / \mathrm{cm}^{2}$ dosimeter was wrapped in a $5-\mathrm{mg} / \mathrm{cm}^{2}$ plastic covering to achieve measurements averaged over a $5-$ to $10-\mathrm{mg} / \mathrm{cm}^{2}$ depth. 
Dose to tissue cannot be directly measured by LiF TL dosimeters because their response is not directiy proportional to tissue dose as a function of source type and energy. The measurements were not directly interpreted as dose. The $T L$ dosimeter data were used to determine the change in dose with and without the phantom in place. The ratios of dose to a small amount of tissue per dose to air are well-known tabulated quantities for the photon sources of interest. Dose to air and exposure are directly related by a unit conversion. These ratios were used to calculate the extremity phantom $C_{x}$ factors.

Phantom design was motivated by the desire to establish a simple design as the standard for future reference calibrations. The design should be easily specified, manufactured, and used. The relationship between the simple designs used for reference calibrations and more realistic phantoms designed to represent occupational conditions should be determined by special measurement.

\subsection{PHANTOM DESIGN}

The phantoms that were considered candidates for use in an extremity standard were chosen to be radially and axially symetric (right circular cylinders or axially colinear, nested, right-circular cylinders). Other asymmetric phantoms were chosen to investigate the effects of the presence of bone near the surface and to investigate the dose to the ends of the finger tips. All phantoms, except the finger tip phantom, were mounted at right angles to the beam direction and extended beyond the beam edges. This eliminated potential effects of phantom-to-air discontinuities on the phantom dose arising from the finite extent of the phantom. The advantage of this technique is to make phantom design and mounting less critical. For the uncolijmated ${ }^{137} \mathrm{Cs}$ exposures, a length of $600 \mathrm{~mm}$ was chosen to approximate a phantom of infinite extent. The exception was the finger phantom designed to determine dose to the tip of the finger. This phantom was made short with a rounded tip on one end. Exposures were performed with the finger tip pointing toward the source.

Polymethyl methacrylate (PMMA) was chosen as the construction material for the plastic portion of the extremity phantoms. This material is specified 
for the simulated whole-body phantoms in the ANSI N13.11 Standard (ANSI 1983) and is readily available under several tradenames, such as Plexiglas and Lucite.

For those phantoms used to study the effects of bone, two materials were chosen to represent the higher atomic-number composition of bone. The first material was a bone-equivalent plastic mixture, mix code SB5, described by White, Martin and Darlison (1977). The elemental composition and specific gravity are given in Table 2.1. This mixture was designed to have a density and atomic number close to that of bone. It was assumed for this study that the simulation adequately represented the true effects of bone.

The second material was studied to investigate the possibility of using a readily available material to simulate the effects of bone for standard phantom specifications. The material chosen for study was aluminum. Aluminum is readily obtainable with negligible variations in composition, is easily machined, and has an atomic number greater than the average atomic number of tissue. By comparing solid plastic, plastic with a bone-equivalent center, and plastic with an aluminum center, estimates of the true dose to the phantom surface and the sensitivity of the $C_{x}$ factors to phantom construction were obtained.

The properties of bone, aluminum, and muscle are compared in Table 2.2. The photoelectric effect is important for photons below about $50 \mathrm{keV}$ and Compton scattering is important between about $50 \mathrm{keV}$ and $10 \mathrm{MeV}$. The photoelectric mass attenuation coefficient is approximately proportional to $\mathrm{NZ}^{3}$, where $\mathrm{N}$ is the electronic density in electrons/gram and $Z$ is the effective atomic number (White 1978). The linear attenuation (equat to the mass attenuation times the density) is the quantity used to compare the Compton reaction rate in bone, aluminum, and muscle. The linear attenuation coefficient due to Compton scattering is directly proportional to the number of electrons $/ \mathrm{cm}^{3}$ of material. Table 2.2 lists the relevant properties of bone, muscle, and aluminum, including the ratio of the photoelectric mass attenuation of muscle and aluminum to bone, and the ratio of the Compton linear attenuation

- Plexiglas is a registered trademark of Rohm and Haas.

- Lucite is a registered trademark of E.I. duPont de Nemours and Company. 
TABLE 2.1. Composition of Bone-Equivalent Plastic Mix SB5

(White, Martin and Darlison 1977)

\begin{tabular}{cr} 
Element & Percent We \\
\cline { 2 - 2 } H & 2.6 \\
$\mathrm{C}$ & 30.6 \\
$\mathrm{~N}$ & 1.0 \\
0 & 38.9 \\
$\mathrm{Cl}$ & 0.1 \\
$\mathrm{Ca}$ & 26.8 \\
Specific Gravity $=1.87$ &
\end{tabular}

TA8LE 2.2. Comparison of the Properties of Bone, Aluminum, and Muscle

\begin{tabular}{|c|c|c|c|}
\hline Quantity & Bone & Aluminum & Muscle \\
\hline Density $\left(\mathrm{g} / \mathrm{cm}^{3}\right)$ & 1.8 & 2.7 & 1.04 \\
\hline $\begin{array}{l}\text { Electronic Depsity } \\
\left.\text { (electrons } / \mathrm{cm}^{3}\right)\end{array}$ & $3.21 \times 10^{24}$ & $2.9 \times 10^{24}$ & $3.31 \times 10^{24}$ \\
\hline $\begin{array}{l}\text { Ratio of Photoelectric } \\
\text { Mass Attenuation to Bone }\end{array}$ & 1.0 & 1.6 & 0.35 \\
\hline $\begin{array}{l}\text { Ratio to Compton Linear } \\
\text { Attenuation to Bone }\end{array}$ & 1.0 & 1.36 & 0.60 \\
\hline
\end{tabular}

coefficient of muscle and aluminum to bone. From Table 2.2, we see that the aluminum insert will produce a more pronounced effect than bone. However, the magnitude of effects for the phantom with the bone insert will be between the values for the solid phantom and the phantom with the aluminum insert.

Little helpful guidance in choosing dimensions for extremity phantoms exists. The Report of the Task Group on Reference Man (ICRP 1975) lists fractional surface areas for the extremities and the total body. Assuming cylindrical shapes for the extremities, the derived diameters are $80 \mathrm{~mm}$ for the arm and $110 \mathrm{~mm}$ for the leg. These numbers are the average over the total extremity, however, and are an overestimate for the lower extremities. As a check, extremity diameters were also determined for a sampling of individuals at PNL. Average diameters for the wrist, mid-forearm, elbow, and ankle were 
$58,82,91$, and $78 \mathrm{~mm}$, respectively. The sample standard deviation of the diameter for the forearm was calculated to be $10 \mathrm{~mm}$. The 73-mm diameter for the arm/leg phantom was chosen as a compromise between the ankle, wrist, and forearm diameters.

Because of the small mass of the finger phantom, the exact diameter is not critical. Furthermore, for workers, the presence of the other fingers and the hand will perturb the radiation field more than differences in finger diameter. The 19-rim diameter for the finger phantom was chosen because of availability (3/4-in. stock) and because this diameter could be used easiTy with typical ring dosimeter designs.

The dimensions and phantom types are listed in Table 2.3. Phantoms with "A" codes were designed to represent the forearm or the lower leg. Phantoms with "F" codes were designed to represent fingers or toes. Phantom F4 simulated a finger tip. All "A" or "F" phantoms had the same outer diameter and consisted of PMMA except for the specified inserted material.

\subsection{TL DOSIMETER HANDLING}

The use of the thin Vinten dosimeters required the development of special handling techniques. The dosimeters as supplied by the manufacturer were intended for one readout only. Special techniques were formulated to overcome the following problems: 1) the dosimeters could not be annealed in the plastic encasement provided by the manufacturer; 2) the dose response between dosimeters varied by as much as a factor of three; 3 ) the dosimeter offgassing during readout deposited a film on the reader optics causing a steadily changing reader calibration; and 4) dosimeter curling during the readout process caused incomplete readout.

Annealing and reuse procedures were developed to allow the use of sensitivity calibration factors. The original plastic packaging was removed, leaving the LiF phosphor embedded in a high-temperature-resistant adhesive. The phosphor was then annealed at high temperature and handled similar to other LiF dosimeter elements. A special dosimeter-retaining clip was used to minimize dosimeter curling and a $5-\mathrm{mg} / \mathrm{cm}^{2}$ thick black polyethylene cover was added. The manufacturer's estimated thickness of $5 \mathrm{mg} / \mathrm{cm}^{2}$ for the $\mathrm{TL}$ element implies net monitoring depths of 5 to $10 \mathrm{mg} / \mathrm{cm}^{2}$ for this study. The 
TABLE 2.3. Extremity Phantom Designs

\begin{tabular}{|c|c|}
\hline Phantom Code & Description \\
\hline A1 & Solid PMMA with 73-man (2-7/8-in.) diameter \\
\hline $\mathrm{A} 2$ & $\begin{array}{l}\text { PMMA tube with } 73-\mathrm{mm} \text { outer diameter } \\
\text { Aluminum insert with } 60-\pi m(2-3 / 8-i n .) \text { diameter }\end{array}$ \\
\hline A3 & $\begin{array}{l}\text { PMMA tube with } 73-\mathrm{mm} \text { outer diameter } \\
\text { Bone-equivalent insert with } 60-\mathrm{mm} \text { diameter }\end{array}$ \\
\hline A4 & $\begin{array}{l}\text { PMMA tube with } 73-\mathrm{mm} \text { outer diameter } \\
\text { Aluminum insert with } 48-\mathrm{mm}(1-7 / 8-i n .) \text { diameter }\end{array}$ \\
\hline A5 & $\begin{array}{l}\text { PMMA tube with } 73 \text { mm outer diameter } \\
\text { Bone-equivalent insert with } 48-\pi m \text { diameter }\end{array}$ \\
\hline A6 & $\begin{array}{l}\text { PMMA cylinder with } 73-\pi m \text { outer diameter and } 25-\pi m \\
\text { (1-in.) offset hole, } 6 \mathrm{~mm}(1 / 4 \mathrm{in} \text {.) beneath surface } \\
\text { Bone-equivalent insert with } 25-\mathrm{mm} \text { diameter }\end{array}$ \\
\hline$F 1$ & Solid PMMA with 19-mm (3/4-in.) diameter \\
\hline $\mathrm{F} 2$ & $\begin{array}{l}\text { PMMA tube with } 19-\pi m \text { outer diameter } \\
\text { Aluminum insert with } 13-m m(1 / 2-i n .) \text { diameter }\end{array}$ \\
\hline $\mathrm{F3}$ & $\begin{array}{l}\text { PMMA tube with } 19-\mathrm{mm} \text { outer diameter } \\
\text { Bone-equivalent insert with } 13-\mathrm{mm}(1 / 2-i n .) \text { diameter }\end{array}$ \\
\hline F4 & $\begin{array}{l}\text { PMMA tube with 19-mm outer diameter and domed top to } \\
\text { represent a finger tip } \\
\text { Bone-equivalent material molded into cavity (13-mm } \\
\text { diameter) }\end{array}$ \\
\hline
\end{tabular}

dosimeters were reused up to seven times before they were discarded. Pre- and postexperiment calibration factors were developed to determine long-term sensitivity variations in the reader calibration. Detaits of the procedure are given in the appendix.

The effective thickness of the Vinten dosimeters was checked using their response to beta sources. The measured ratio of the response to ${ }^{204} \mathrm{~T} 1$ and ${ }^{90} \mathrm{Sr} /{ }^{90} \mathrm{Y}$ was $0.96 \pm 0.11$. The estimated effective width is 0 to $20 \mathrm{mg} / \mathrm{cm}^{2}$, based on the measured depth dose curves for those sources. The variation in effective thickness for the sampled dosimeters contributed to the uncertainty of the measurement. The verified effective width is sufficient to meet the goats of the dose-response measurements for photons. 


\subsection{EXPERIMENTAL DESIGN}

The TL dosimeters were exposed, read out, and annealed in sets of 60 to 80 dosimeters. Both in-air and on-phantom exposures were included with each set, as well as 10 dosimeters exposed to ${ }^{137} \mathrm{Cs}$ under $100 \mathrm{~mm}$ of plastic and 2 unexposed dosimeters. A total of 5 exposure sets were used, each for up to 7 cycles. Background signals ranged from $1 \%$ to $2 \%$ of the exposed dosimeter readings. The ${ }^{137} \mathrm{Cs}$-calibrated dosimeters were used to relate measurements made in separate cycles and to track dosimeter degradation. All dosimeters for each set were exposed to ${ }^{137} C_{s}$ under $100 \mathrm{~mm}$ of plastic at least twice, from which TL element sensitivity factors were developed. The on-phantomto-in-air ratios were calculated following corrections for TL element sensitivity and background subtraction.

Not all combinations of beam type and energy and phantom construction were used for the experiment because of limited time and resources. The data for the solid PMMA phantoms ( $A 1$ and F1) were collected for nearly all energies to provide reference energy response curves. Data for all phantoms were collected for three $x$-ray techniques $(16,60$, and $120 \mathrm{keV}$ ) to determine the effects of phantom construction in the energy ranges most likely to result in observable differences. Measurements at additional energies were performed for the phantom with the 60-nm bone-equivalent insert (A3) to better determine the energy dependence of observed differences compared to results for the solid PMMA arm phantom. The dependence of the technique on variations in beam setup and $T L$ dosimeter readout were tested by doing many replicate measurements for the same setups. Differences because of setup variations were not observed and were presumed less than the random uncertainties in the $T L$ dosimeter readings.

The irradiation source properties are listed in Table 2.4. The dependence of the response to photon energy was measured using $K$-fluorescence $x$ rays (Kathren, Rising and Larson 1971; IOS 1979) ranging from 16 to $76 \mathrm{keV}$, heavily filtered bremsstrahlung techniques with effective energies of 120 and $211 \mathrm{keV}$ (NBS 1981) and ${ }^{137} \mathrm{Cs}$ and ${ }^{60} C_{0}$ isotopic sources. Measurements were also performed using three of the bremsstrahlung techniques (M30, S60, and M150) specified in ANSI N13.11 (1983). The source designations for the K-fluorescence 
TABLE 2.4. Irradiation Source Properties

K-Fluorescence $X$ Rays

\begin{tabular}{cc}
$\begin{array}{c}\text { Source } \\
\text { Designation }\end{array}$ & $\begin{array}{c}\text { Average } \\
\text { Energy, keV }\end{array}$ \\
\cline { 2 - 2 } K16 & 16 \\
K23 & 23 \\
K31 & 31 \\
K40 & 41 \\
K49 & 50 \\
K59 & 60 \\
K75 & 76
\end{tabular}

Bremsstrahlung $X$ Rays

\section{Source \\ Designation}

M30

S60

M150

H150

H250

\section{Average or \\ Effective \\ Energy, keV}

20

36

70

120

211

Isotopic Sources

\begin{tabular}{rlr} 
Designation & Source Type & Average Energy, keV \\
\cline { 2 - 3 }${ }^{137}{ }^{60} \mathrm{Cs}$ & Photon & 662 \\
${ }^{90} \mathrm{Cr} /{ }_{\mathrm{So}}$ & Photon & 1250 \\
& Beta & 800
\end{tabular}

beams follow the energy of the $k_{\alpha 1} x$-ray transition and differ from the average energy of the technique. Measurements were also performed with a ${ }^{90} \mathrm{Sr} /{ }^{90} \mathrm{Y}$ beta particle source.

The TL dosimeter readings were used to determine on-phantom to in-air ratios that represented the effects of the presence of the phantom. The value estimated by the TL measurements was the dose to tissue inside the phantom at the $7-\mathrm{mg} / \mathrm{cm}^{2}$ depth divided by the dose to a small mass of tissue in air. The errors due to the $\mathrm{TL}$ response differences compared to tissue dose were assumed to nearly cancel when the ratio was taken. The $c_{x}$ values were calculated using the following formula: 


$$
C_{x}=B F \cdot f
$$

where $B F$, or backscatter factor, is the ratio of the tissue dose on phantom to the tissue dose in air and $f$, or $f$ factor, is the ratio of the tissue dose in air to the exposure in air. The backscatter factor was approximated by the measured on-phantom to in-air ratios. The $f$ factor is a tabulated, slowly varying function of energy. The $f$ factors for muscle tissue were taken from NCRP 69 (NCRP 198I) and are listed in Table 2.5 for the beam energies and types used for this study.

TABLE 2.5. Exposure-to-Dose Conversion Factors (Small Mass Limit)

Source Designation Conversion Factor for

K16 Muscle (f), rad/R

K23

0.871

K3I

0.864

K40

0.863

K49

0.868

K59

0.886

K75

0.901

0.925

M30

0.865

560

0.866

MI50

0.915

H150

0.948

H250

0.957

${ }^{137} \mathrm{Cs}$

0.958

${ }^{60} \mathrm{Co}$

0.958 



\subsection{RESULTS}

The measurement results and the uncertainty analysis are presented. The use of $T L$ dosimeters for the determination of $C_{x}$ factors was checked by performing measurements on slab body phantoms and comparing the results to tabuTated factors. These measurements are described in Section 3.1 and are used in the uncertainty analysis presented in Section 3.3. The extremity phantom measurements are described in Section 3.2.

\subsection{TECHNIQUE VERIFICATION MEASUREMENTS}

The measurement technique used is not exact because of the nontissueequivalent response of the $T L$ dosimeters. Measurements were performed on slab body phantoms and compared to tabulated $C_{x}$ values to help determine an upper limit to the systematic errors associated with this method. The systematic measurement errors for the extremity phantom measurements are smaller than for the body phantom measurements because the surface dose due to scattering in the phantom is less.

The energy dependence of the response of the dosimeters was determined at a given photon energy by taking the ratio of the TL readings for the in-air exposures and ${ }^{137} \mathrm{Cs}$-calibration exposures. Because a 11 expose-read-anneal cycles included the ${ }^{137} C_{s}$ calibration, these data represent direct response ratios without further corrections. The data is presented in Table 3.1 along with the uncertainty associated with the variability of the $T L$ readings. The energy response function is plotted in Figure 3.1. The results are normalized to the response for the ${ }^{137}$ Cs in-air exposure for convenience. The overresponse of the TL signal reaches a maximum of approximately 1.6 at low energies ( 20 to $30 \mathrm{keV}$ ). The data deviates from a smooth curve only to an extent consistent with measurement error.

The $c_{x}$ factors for the body phantoms were determined as described in Section 2. The results are given in Table 3.2. Only shallow $c_{x}$ factors were determined in correspondence to the extremity measurements. The first column presents the source designation. The K-fluorescence sources were used up to K59 technique along with three of the bremsstrahlung techniques specified in 
TABLE 3.1. Energy-Dependent Response of the Thin Dosimeters

\begin{tabular}{|c|c|c|}
\hline Beam & $\begin{array}{r}\text { Average or } \\
\text { Effective } \\
\text { Energy, keV } \\
\end{array}$ & $\begin{array}{c}\text { In-Air Response/Dose to Air, } \\
\text { Normalized to }{ }^{137} \mathrm{Cs} \\
\end{array}$ \\
\hline K16 & 16 & $1.52 \pm 0.02$ \\
\hline K23 & 23 & $1.58 \pm 0.09$ \\
\hline K31 & 31 & $1.50 \pm 0.09$ \\
\hline K40 & 40 & $1.47 \pm 0.03$ \\
\hline K49 & 49 & $1.44 \pm 0.04$ \\
\hline K59 & 60 & $1.32 \pm 0.02$ \\
\hline K75 & 77 & $1.18 \pm 0.04$ \\
\hline H150 & 120 & $1.24 \pm 0.02$ \\
\hline $\mathrm{H} 250$ & 211 & $1.18 \pm 0.02$ \\
\hline${ }^{131} \mathrm{Cs}$ & 662 & $1.00 \pm 0.02$ \\
\hline${ }^{60} \mathrm{Co}$ & 1250 & $1.01 \pm 0.02$ \\
\hline
\end{tabular}

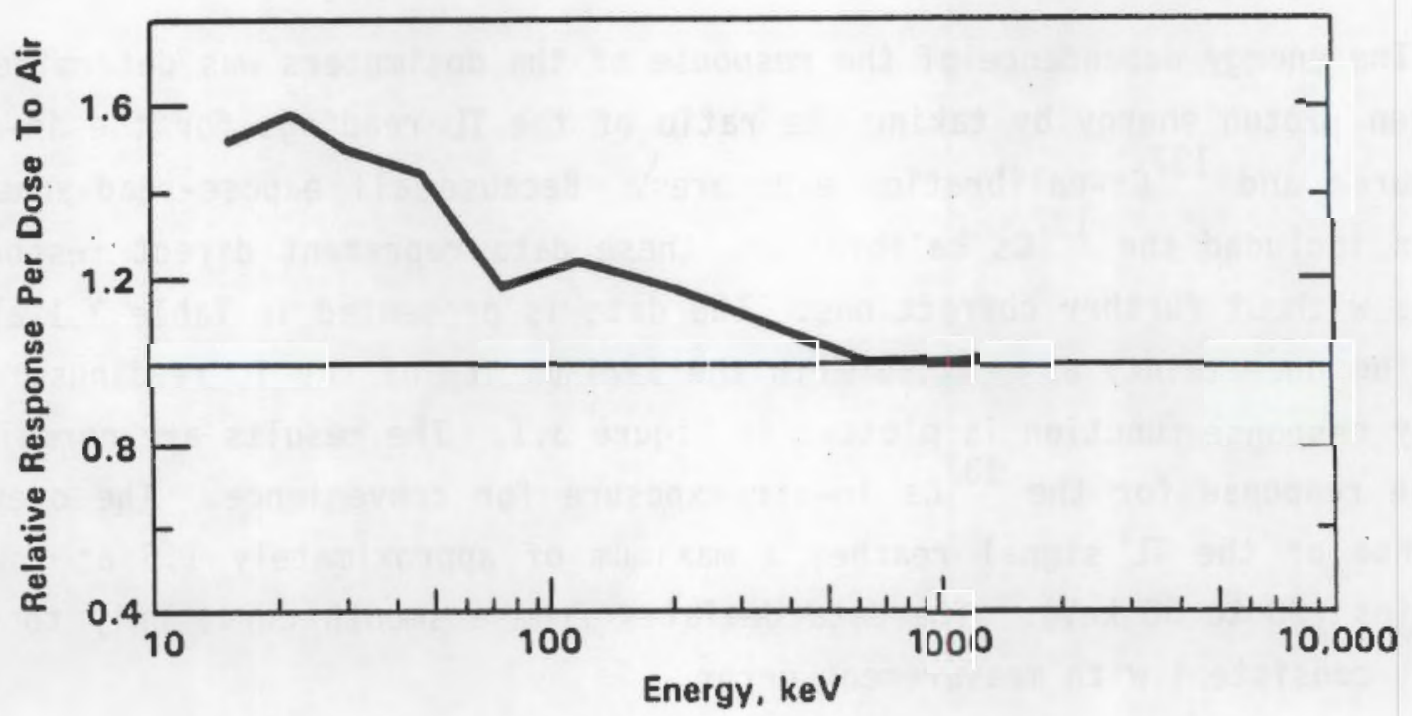

FIGURE 3.1. Energy-Dependent Response for the Thin TL Dosimeters. (Data normalized to the results for ${ }^{137} \mathrm{Cs}, 662 \mathrm{keV}$. ) 
TABLE 3.2. Comparison of Shallow $C_{x}$ Factors for Body Phantoms

\begin{tabular}{|c|c|c|c|c|c|}
\hline \multirow[b]{2}{*}{$\begin{array}{c}\text { Source } \\
\text { Designation }\end{array}$} & \multicolumn{3}{|c|}{ S1 ab Phantom, PKL Plastic } & \multirow{2}{*}{$\begin{array}{c}\text { Sl ab Phantom, } \\
\text { PMinA } \\
\text { Present } \\
\text { Messuremont }\end{array}$} & ICRU Sphere \\
\hline & $\begin{array}{l}\text { Monte }{ }^{(a)} \\
\text { Carlo } \\
\end{array}$ & $\begin{array}{c}\text { TEEC } \\
\text { Messurement } \\
\end{array}$ & $\begin{array}{c}\text { Present } \\
\text { Measuresent } \\
\end{array}$ & & $\frac{\mathrm{TE}^{(\mathrm{C})} \text { Material }}{\text { Monte Carlo(d) }}$ \\
\hline $\begin{array}{l}K 16 \\
\text { K23 } \\
\text { K31 } \\
\text { K40 } \\
\text { K49 } \\
\text { K59 }\end{array}$ & $\begin{array}{l}0.88 \\
1.01 \\
1.13 \\
1.33 \\
1.53 \\
1.62\end{array}$ & $\begin{array}{l}1.08 \\
1.07 \\
1.07 \\
1.20 \\
1.36 \\
1.48\end{array}$ & $\begin{array}{l}0.85(03)^{(\theta)} \\
1.03(02) \\
1.08(05) \\
1.33(08) \\
1.34(03) \\
1.42(07)\end{array}$ & $\begin{array}{l}0.93(03) \\
1.00(02) \\
1.16(04) \\
1.39(03) \\
1.59(04) \\
1.69(05)\end{array}$ & $\begin{array}{l}0.90 \\
0.99 \\
1.13 \\
1.34 \\
1.48 \\
1.52\end{array}$ \\
\hline $\begin{array}{l}\text { M30 } \\
S 60 \\
M 150\end{array}$ & $\begin{array}{l}- \\
-\end{array}$ & $\begin{array}{l}1.08 \\
1.15 \\
1.41\end{array}$ & $\bar{z}$ & $\begin{array}{l}0.94(03) \\
1.32(07) \\
1.47(06)\end{array}$ & $\begin{array}{l}0.92 \\
1.14 \\
1.43\end{array}$ \\
\hline
\end{tabular}

(a) Values taken or interpolated from R. F. Nel son (1984).

(b) Measurements performed with a tissue-equivalent extrapolation chamber (TEEC) (Yoder et al. 1979). Some of the values are interpolated.

(c) TE is tissue equivalent.

(a) Values taken or interpolated from ANSI M13.11 (1983). They are based on Monte CarTo calculations using the ICRU sphere (Dimbylow and Francis i979).

(e) $0.85(03)$ is read $0.85 \pm 0.03$.

ANSI N13.11 (1983). The next three columns contain values for the slab phantom employing plastic developed by the Pacific Northwest Laboratory (PNL). This polyurethane-based plastic composition was used as a tissue substitute by Yoder et al. (1979) for direct measurements of the $C_{x}$ factors using a tissueequivalent extrapolation chamber (TEEC). Nelson and Chilton (1982) and Nelson (1984) compared results for this plastic and for international Commission on Radiation Units and Measurements (ICRU) tissue using a Monte Carlo technique and reported close agreement. Note that the experimental measurements by Yoder et al. differ from the Monte Carlo calculations for the same phantom geometry, principally at the very low energies but also at mid $x$-ray energies (see 659 values). The present measurements agree more closely with the Monte Carlo values at the lowest energies and with the TEEC measurements at the mid energies. The $K 59$ and $K 49$ data points are 14\% lower than the Monte Carlo calculations. However, the agreement between the Yoder et a1. (1979) measurement and the present data suggests that the bias cannot be entirely attributed to the present technique.

The last two columns in Table 3.2 compare the $C_{x}$ factors specified in ANSI N13.11 (1983) with the present measurements performed on the ANSI N13.11 phantom. The potential for bias not related to this measurement technique is 
greater than for the PNL-plastic phantom data because the ANSI N13.11 values are based on Monte Carlo calculations for the ICRU sphere (Dimbylow and Frances 1979). Agreement is good at the lower energies. The discrepancy increases with increasing energy, rising to $+11 \%$ for the $k 59$ source. The difference in phantom scatter has been documented for the slab geometry compared to the spherical geometry. Nelson (1984) calculated the difference at $60 \mathrm{keV}$ from between $+14 \%$ and $+17 \%$, depending on the tissue constituents used. Ehrlich and Soares (1984) measured the effect of the phantom geometry difference by a TL dosimeter method using PMMA phantoms representing both the sphere and the slab geometries. Results for the shallow depth interpolated to $60 \mathrm{keV}$ indicated a ratio of 1.05 with an uncertainty of $5 \%$. It is reasonable to attribute the $11 \%$ overresponse to the difference in geometries. In fact, the agreement between the present measurements on the PMMA phantom and the Monte Carlo calculations for either the PNL-plastic or ICRU-tissue slab phantom is good.

For the bremsstrahlung beams, the agreement between the present measurements and the $C_{x}$ factors in ANSI NI3.11 is good except for the S60 source in which the discrepancy represents about 2.5 standard deviations. The cause of this discrepancy is unclear. The $C_{x}$ factor for the average energy of the S60 technique ( $36 \mathrm{keV}$ ) estimated from the $K-f 7 u o r e s c e n c e$ data is within one standard deviation for the present measurements. The value from the ANSI N13.11 standard is nearly equal to the value for the K3I source. This is indicative that the discrepancy may not be primarily due to a bias in the present technique. Even though some discrepancies for the body phantom measurements are apparent, the accompanying uncertainties in the correct values for the Monte Carlo and extrapolation chamber techniques implies that the overa 11 bias in the present $T L$ dosimeter technique is less than $15 \%$ of the scatter contribution in the worst case (approximately 0.10 in the value for the $\mathrm{K} 59$ source). The bias of the $\mathrm{TL}$ dosimeter technique is most likely less than this upper limit value.

\subsection{EXTREMITY PHANTOM MEASUREMENTS}

The measured on-phantom-to-in-air ratios were used in Equation (2.1) to determine the $c_{x}$ factors. These measured ratios are listed in Table 3.3 along 
TABLE 3.3. Measured On-Phantom-to-In-Air Ratios for Extremity Phantoms

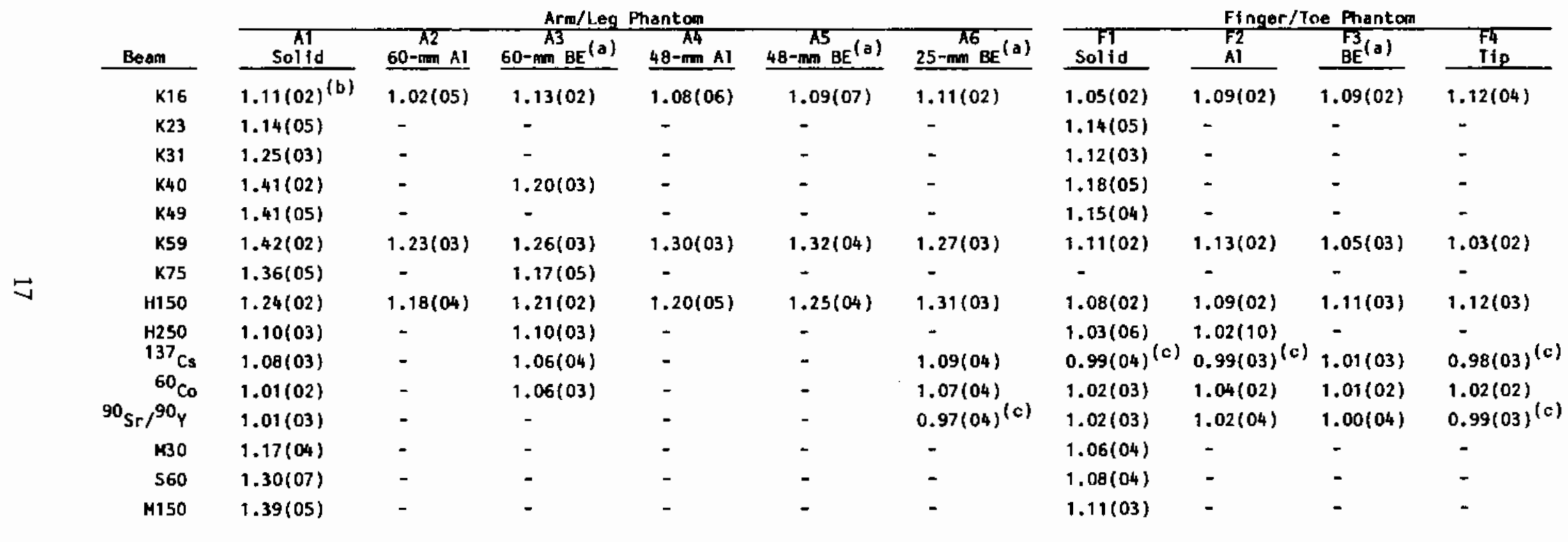

(a) BE is bone equivalent.

(b) $1.11(02)$ is read $1.11 \pm 0.02$.

(c) Ratios less than 1 are attributed to measurement error. 
with the estimated one standard deviation uncertainty for the random measurement error. This uncertainty estimate was derived from the variability of the $T L$ readings. Some of the entries represent only one measurement (of at least five dosimeters each for the numerator and denominator of the ratio), while others represent several replicate measurements. The minimum quoted random uncertainty was set at 0.02 . The table presents the measured ratios as a function of phantom design and source designation.

The energy dependence of the ratio was determined for the solid PMMA phantoms. The response for the other phantoms was checked for only selected energies. A significant difference was found between the response ratio for the finger and the arm phantoms, as expected. The level of scatter observed for the finger phantoms was sufficiently small so that differences between phantom designs were typically smaller than the uncertainties of the measured ratios except possibiy for the $\mathrm{k59}$ technique. The ratio for the finger-tip phantom is significantly (99\% confidence level) lower than for the phantoms mounted perpendicular to the beam axis. Significant differences in the scatter response for the arm phantoms were found for energies between 40 and $100 \mathrm{keV}$.

The response ratios as a function of energy are plotted in Figure 3.2 for the solid arm and finger phantoms and the arm phantom with bone-equivalent insert. The response ratio for the solid plastic arm phantom is systematically greater than the ratio for the phantom with bone-equivalent insert between 30 and $100 \mathrm{keV}$. This effect is probably a result of the fundamental interactions involved.

The primary process contributing to the backscatter of photons at these energies is compton scattering. The energy of the Compton-scattered photons is less than the primary-beam energy (approximately $20 \%$ less at $60 \mathrm{keV}$ for a backscattered photon). The probability of the photoelectric process increases with increasing atomic number and decreasing energy, increasing the absorption of the Compton-scattered photons in the higher atomic number material. The ratio of the mass attenuation coefficient for $50 \mathrm{keV}$ to that for $60 \mathrm{keV}$ increases from 1.07 for plastic to 1.28 for bone. The deposition of energy per unit mass (dose) is greater for the higher atomic number material because it is more efficient in converting photon energy to electron 


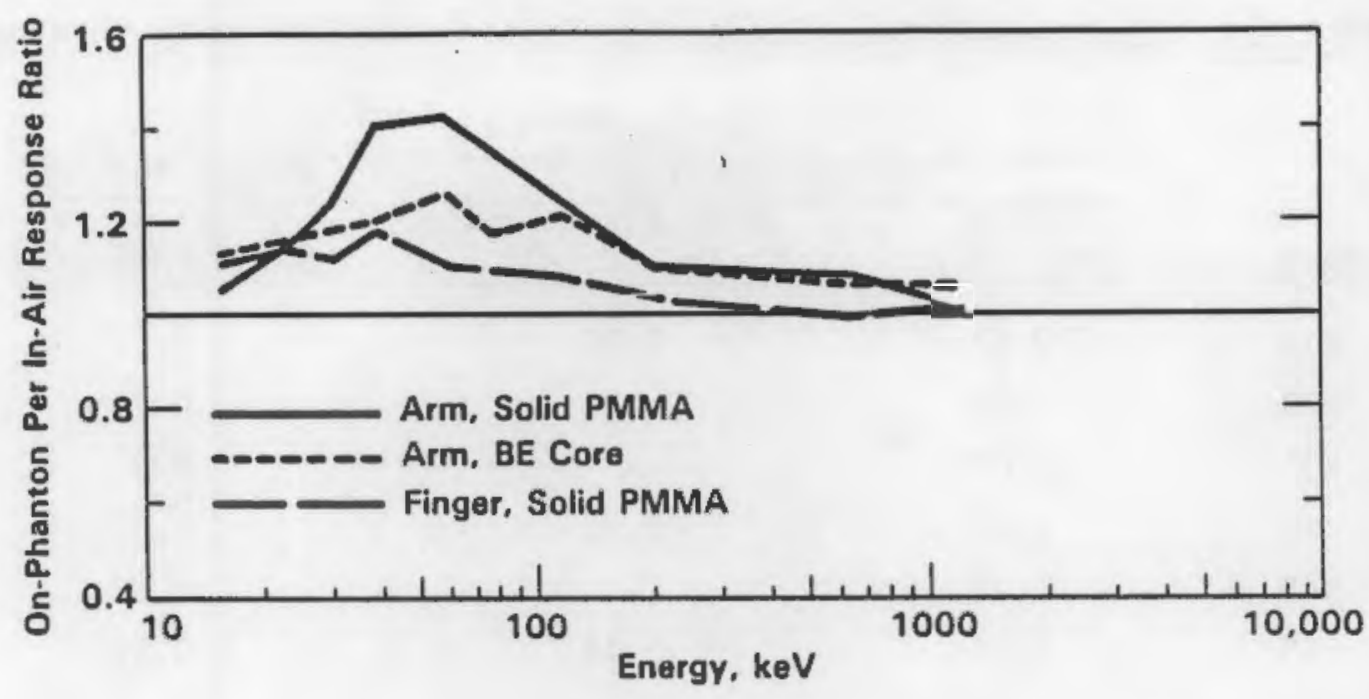

FIGURE 3.2. Energy Dependence of the Response Ratios for the On-Phantom-to-In-Air Ratios

kinetic energy, for both the primary and the secondary photon fields. The electrons backscattering from the higher atomic number material are absorbed in the plastic cylinder, so that only the backscattered photon field penetrates to contribute to the surface dose. The greater absorption of the scattered photons in the higher atomic number material decreases the surface dose compared to the dose for the solid PMMA phantom.

The measured ratios for all of the arm phantoms with inserts are similar. The measured ratios for the $60-\mathrm{mm}$ inserts and the $25-\mathrm{mm}$ insert are approximately the same. They all were placed at a depth of $6 \mathrm{~mm}$ from the phantom surface. The averaged ratios for the phantoms for the smaller (48- $\mathrm{mm})$ inserts were larger than those for the larger inserts by approximately two standard deviations. The differences observed between the aluminum inserts and the bone-equivalent inserts were not statistically significant. The depth of the higher atomic number insert is more important than its size or composition.

The derived $C_{x}$ factors are listed in Table 3.4 for the arm or leg phantoms of solid PMMA and of the $60-\mathrm{mm}$ bone equivalent material plus PMMA shell and for the finger phantom of solid PMMA. The $C_{x}$ values range up to 
TABLE 3.4. Exposure-to-Dose Conversion Factors for Extremity Phantoms

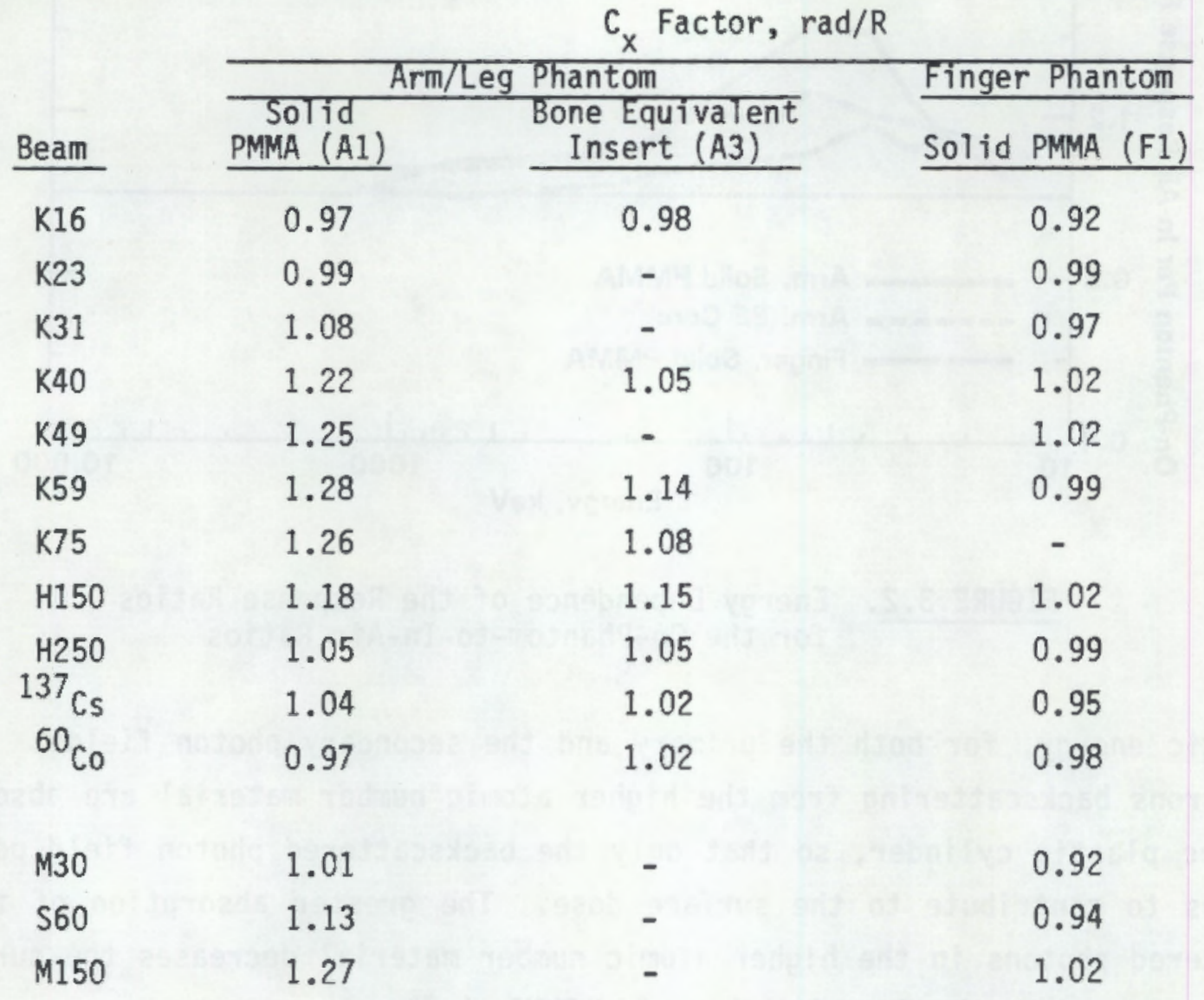

1.28 for the solid PMMA arm or leg phantom, and up to 1.15 for the arm or leg phantom with bone equivalent insert. The $C_{x}$ values for the finger phantom are all near unity.

\subsection{UNCERTAINTY ANALYSIS}

Measurement errors have a random component and a systematic component. Random uncertainties are estimates of the magnitudes of the measurement errors that vary for each measurement performed under the same conditions. Random errors can alter the numerical results if the data were collected again using the same equipment and techniques. Random uncertainties, which are estimates of the probable magnitudes of the random errors, have been estimated from the variability of the $\mathrm{TL}$ dosimeter readings and are given in Table 3.3. 
The systematic errors are all others that effect the outcome of the measurement. Upper-limit estimates of those factors identified as contributing to the total error are listed in Table 3.5 for three example sources. The total uncertainty of the derived $C_{x}$ factors can be estimated by calculating the sum of the systematic uncertainty and twice the random uncertainty (95\% confidence level) derived from the measured ratios. For example, the total uncertainties at the $95 \%$ confidence level for the $\mathrm{K} 16, \mathrm{~K} 59$, and ${ }^{137} \mathrm{Cs}$ factors for the solid arm phantom are $4.8 \%, 4.9 \%$, and $6.9 \%$, respectively. The systematic uncertainty due to the TL dosimeter energy response estimated for the K59 beam (1.8\%) represents $6 \%$ of the dose attributed to phantom backscatter. This compares to the upper limit of $15 \%$ derived from the body phantom measurements. The $6 \%$ estimate, based on the effective energy of the backscattered photons and the energy response of the TL material, is considered a better estimate than the derived limit of $15 \%$.

TABLE 3.5. Systematic Uncertainties

\begin{tabular}{|c|c|c|c|}
\hline \multirow[b]{2}{*}{ Contributor } & \multicolumn{3}{|c|}{$\begin{array}{l}\text { Uncertainty Upper Limit } \\
\text { Estimate, \% }\end{array}$} \\
\hline & $\mathrm{K} 16$ & $\mathrm{~K} 59$ & ${ }^{137} \mathrm{Cs}$ \\
\hline f-Factor & $<1$ & $<1$ & $<1$ \\
\hline $\begin{array}{l}\text { TL Dosimeter } \\
\text { Energy Response }\end{array}$ & 0.2 & 1.8 & 0.8 \\
\hline Exposure Delivery & 0.4 & 0.4 & 0.2 \\
\hline Beam Energy & $\underline{0.5}$ & $\underline{0.3}$ & $N^{(a)}$ \\
\hline Total & 1.2 & 2.1 & 1.3 \\
\hline
\end{tabular}





\subsection{CONCLUSIONS}

Exposure-to-dose conversion factors were determined for severat simple phantom designs by measuring the ratio of the (tissue) dose on the phantom surface to the (tissue) dose in air. The measurement technique chosen using thin LiF TL dosimeters included some systematic error; however, the goal of a total uncertainty of near $5 \%$ was achieved for most of the data set. The technique was partially verified through a comparison of measurements on body phantoms to tabulated values from the literature. The value of the comparison was $l$ imited because of the uncertainty of the tabulated data and geometry differences between the measurement conditions and the conditions for the tabulated values.

Significant differences in the determined $C_{x}$ factors were found for the phantoms investigated. The factors for the finger phantoms were uniformly less than for the arm or leg phantoms. The factors for the finger phantoms did not significantly vary with phantom construction because the contribution to the surface dose from the phantom remained small at all energies. The factors for the arm or leg phantoms with either bone-equivalent or aluminum inserts were less than that of the solid PMMA phantom over the energy range from approximately 40 to $100 \mathrm{keV}$. This effect was attributed to the preferential absorption of the lower energy backscattered photons in the higher atomic number material of the insert. The differences in factors between the phantoms using the bone-equivalent core and the phantoms with the aluminum core were less than the experimental uncertainty at the energies providing the greatest level of backscatter. The observed variation on the size of insert was $+8 \%$ at $60 \mathrm{keV}$ for the 48 - $\mathrm{mm}$ diameter compared to the $60-\mathrm{mm}$ diameter inserts.

Due to the small variation of the $C_{x}$ factor with phantom composition for the finger phantom, the solid PMMA phantom is recommended for use in routine calibrations. Because of the relatively large dependence on phantom construction observed at middle $x$-ray energies for the arm or leg phantom, a phantom with an insert of higher atomic number material is recommended for use. Closer correspondence between surface dose for the calibration phantom and surface dose on the extremity of the worker for the same radiation field 
conditions should result. The position of the material below the surface of the phantom is more important than the size of the insert. For the simplest design, the phantom with the aluminum insert is recommended for use. The diameter of the insert may vary between 48 and $60 \mathrm{~mm}$ inclusive, without resulting in a large difference in $C_{x}$ factors.

The use of the $C_{x}$ factors given in Table 3.4 is awkward because of the variation of the values attributed to experimental error. The data were used to develop smooth curves as a function of energy, resulting in improved estimates of the $C_{x}$ factors over the range from 15 to $1500 \mathrm{keV}$. This data is presented in Table 4.1 for the solid PMMA arm or leg phantom, the $60-\mathrm{mm}$

TABLE 4.1. Exposure-to-Dose Conversion Factors (smoothed data)

\begin{tabular}{|c|c|c|c|c|}
\hline \multirow[b]{2}{*}{ Energy } & \multicolumn{2}{|c|}{ Arm/Leg } & \multirow[b]{2}{*}{$\begin{array}{l}\text { Finger /Toe } \\
\text { Solid PMMA }\end{array}$} & \multirow{2}{*}{$\begin{array}{l}\operatorname{ICRU}^{(a)} \\
\text { Sphere }\end{array}$} \\
\hline & Solid PMMA & $\begin{array}{c}\text { Bone Equivalent } \\
\text { Insert }\end{array}$ & & \\
\hline 15 & 0.96 & 0.96 & 0.92 & 0.90 \\
\hline 20 & 0.99 & 0.99 & 0.95 & 0.94 \\
\hline 30 & 1.08 & 1.03 & 0.98 & 1.11 \\
\hline 40 & 1.21 & 1.06 & 0.99 & 1.34 \\
\hline 50 & 1.26 & 1.10 & 0.99 & 1.50 \\
\hline 60 & 1.28 & 1.13 & 1.00 & 1.52 \\
\hline 80 & 1.25 & 1.15 & 1.01 & 1.48 \\
\hline 100 & 1.21 & 1.15 & 1.02 & 1.43 \\
\hline 120 & 1.16 & 1.13 & 1.02 & 1.36 \\
\hline 150 & 1.10 & 1.10 & 1.01 & 1.30 \\
\hline 200 & 1.07 & 1.07 & 1.00 & 1.22 \\
\hline 300 & 1.04 & 1.04 & 0.99 & 1.12 \\
\hline 400 & 1.03 & 1.03 & 0.99 & 1.08 \\
\hline 600 & 1.02 & 1.02 & 0.98 & 1.03 \\
\hline 800 & 1.01 & 1.01 & 0.98 & 1.03 \\
\hline 1000 & 1.00 & 1.00 & 0.98 & 1.02 \\
\hline 1500 & 0.99 & 0.99 & 0.98 & 1.00 \\
\hline
\end{tabular}

(a) Dimbylow and Frances (1979). 
bone-equivalent center arm or leg phantom, and the solid PMMA finger phantom. The values for the ICRU sphere are also listed for comparison (Dimbylow and Francis 1979). The values over most of the energy range are consistent, with the maximum factors for the solid PMMA arm or leg phantom and the ICRU sphere occurring at the same energy. There is an unexplained difference at the very lowest energies of approximately $5 \%$. Figure 4.1 presents the data with one standard deviation random uncertainties together with the developed smooth curves for the three phantoms.

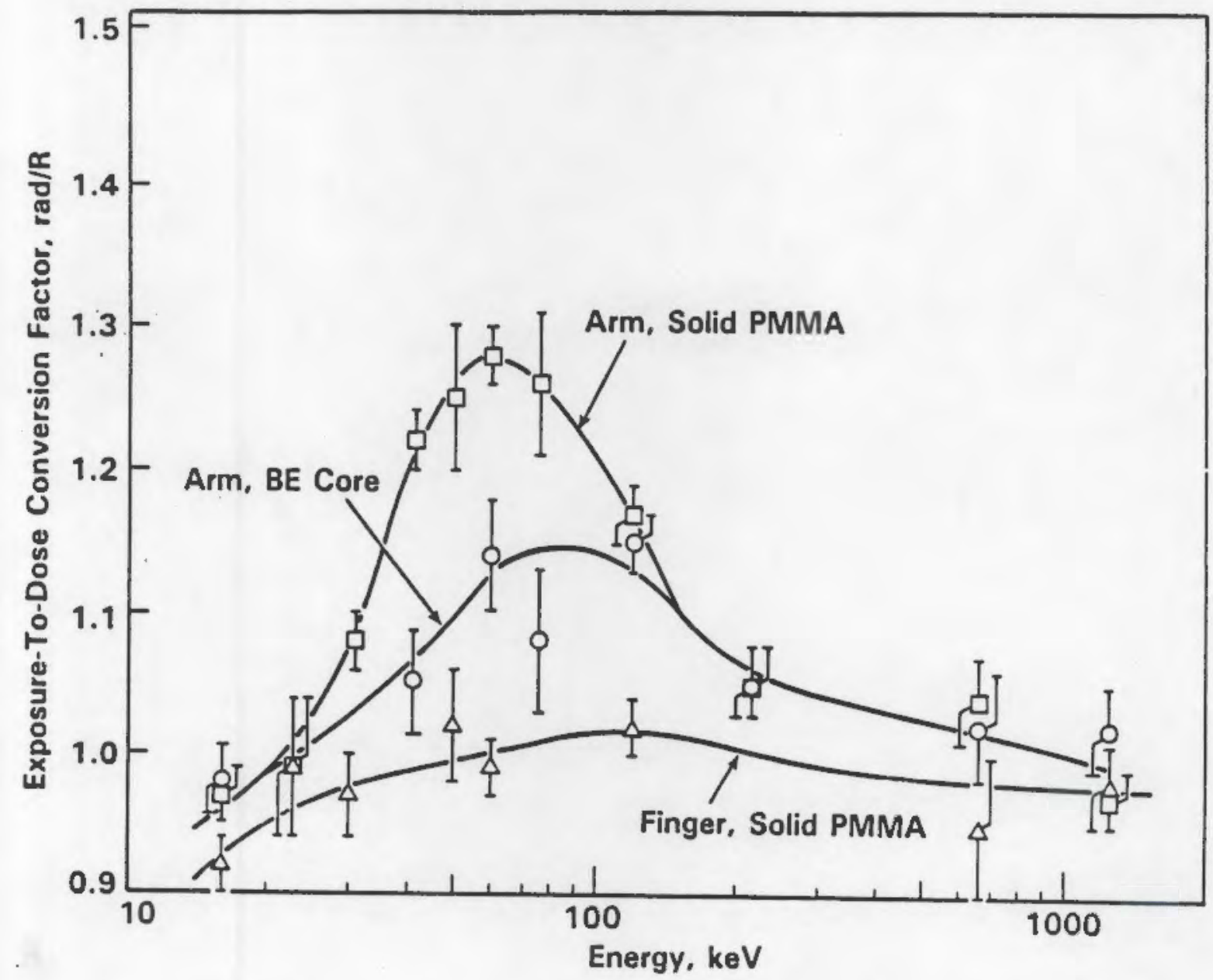

FIGURE 4.1. The $C_{\text {D }}$ Data with One Standard Deviation Random Uncertainties and Dêrived Smooth Curves 



\section{REFERENCES}

American National Standards Institute (ANSI). 1983. Criteria for Testing Personnel Dosimetry Performance. ANSI- N13.11, American National Standards Institute, New York.

Dimbylow, P. J., and T. M. Francis. 1979. A Calculation of the Photon DepthDose Distributions in the ICRU Sphere for a Broad Parallel Beam, A Point Source and an Isotropic Field. NRPB 92, National Radiological Protection Board, Harwe T, England.

Dutt, J. C., K. Chongkitivitya, R. J. Pattison, J. C. Stewart and A. McWhan. 1984. "The Performance of a New Extremity and Skin Dosemeter." Radiation Protection Dosimetry 6(1-4):257-266.

Ehrlich, M., and C. G. Soares. 1984. "Effect of Phantom Geometry on the Conversion Factor From Expcsure to Absorbed Dose." Radiation Pretection Dosimetry 8(4):261-263.

Kathren, R. L., F. L. Rising and H. V. Larson. 1971, "K-FTuorescence X-Rays: A Mutti-Use Tool for Health Physics." Health Physics 21(2):265-293.

International Commission on Radiological Protection (ICRP). 1975. Report of the Task Group on Reference Man. ICRP Publication 23, Pergamon Press, New York.

International Organization for Standardization (IOS). 1979. $X$ and $Y$ Reference Radiation for Calibrating Dosimeters and Dose Ratemeters and for Determining Their Response as a Function of Photon Energy. ISO 4037, UDC 53534-36:539.165:53.089.6, Geneva, Switzerland.

National Council on Radiation Protection and Measurements (NCRP). 1981. Dosimetry of X-Ray and Gamma-Ray Beams for Radiation Therapy in the Energy Range $10 \mathrm{keV}$ to $50 \mathrm{MeV}$. NCRP Report No. 69, National Council on Radiation Protection and Measurements, Washington, D.C.

Nelson, R. F., and A. B. Chilton. 1982. "Depth Doses in Slab Phantom for Low Energy Monoenergetic Photons." Radiation Protection Dosimetry 1(4):285-289.

Nelson, R. F. 1984. Low Energy Photon Dose Deposition in Tissue Slab and Spherical Phantoms. Ph.o. Thesis, University of ITinois at UrbanaChampaign, Urbana, Illinois.

U.S. National Bureau of Standards (NBS). 1981. Calibration and Related Measurement Services of the National Bureau of Standards. NBS Speciat Publication 250, U.S. Government Printing office, Washington, D.C.

White, D. R., R. J. Martin and R. Darlison. 1977. "Epoxy Resin Based Tissue Substitutes." British Journal of Radiation 50:914. 
White, D. R. 1978. "Effective Atomic Numbers in the Formulation of Tissue Substitute Materials for Photons." Radiation Research 76:23-31.

Yoder, R. C., W. T. Bartlett, J. W. Courtney, C. D. Hooker, J. A. Holland and B. T. Hogan. 1979. Confirmation of Conversion Factors Relating Exposure and Dose-Equivalent Index Presented in ANSI N13.11. NUREG/CR-1057, PNL-3219, Pacific Northwest Laboratory, Richtand, Washington. 
APPENDIX

PROCEDURES FOR USE OF VINTEN THIN TL DOSIMETERS 


\section{APPENDIX}

\section{PROCEDURES FOR USE OF VINTEN THIN TL DOSIMETERS}

Procedures for the use and handling of thin TL dosimeters manufactured by Vinten Instruments were developed to allow annealing and reuse. Element sensitivity correction factors were determined to allow precise measurements to be performed. The procedure follows.

1. Remove the black $7-\mathrm{mg} / \mathrm{cm}^{2}$ plastic tape from the dosimeter face and discard the "bandaid" holder.

2. With scissors, trim the Teflon tape from around the dosimeter.

3. Place the trimmed dosimeters in a petri dish face upwards.

4. Place the petri dish (without cover) in a furnace that has been preheated to $275^{\circ} \mathrm{C}$.

5. Off-gas and anneal dosimeters for 15 minutes.

6. Remove petri dish and dosimeters from furnace (under reduced light - no fluorescent light) and place in a $100^{\circ} \mathrm{C}$ preheated oven for 2 hours. This resensitizes the dosimeter phosphor.

7. Place dosimeters in a light-tight, radiation-shielded storage location until thoroughly cooled, preferably for several hours.

8. Fabricate a $5-\mathrm{mg} / \mathrm{cm}^{2}$-thick holder from black polyethylene plastic. The holder is a small pouch large enough to hold one dosimeter.

9. Mount the dosimeters in the holders and label holders to retain dosimeter identification. Expose to 1 rad ${ }^{137} \mathrm{Cs}$ at a depth of $1 \mathrm{~cm}$ in plastic. Store dosimeters in a dark, shielded storage location until readout.

10. Fabricate a means of holding the dosimeter in a flat restrained position on the TL reader planchet. (A small platinum wire loop was used.)

11. Read out dosimeters under a nitrogen atmosphere, not exceeding $275^{\circ} \mathrm{C}$ during the readout process.

12. Repeat exposure/readout cycle for the experiment and a post experiment calibration to the ${ }^{137} \mathrm{Cs}$ source. (At least six cycles were performed before dosimeter deterioration was observed.)

- Tefton is a registered trademark of E. I. duPont de Nemours and Company. 


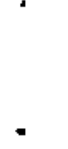

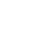




\section{DISTRIBUTION}

No. of

Copies

OFFSITE

30 Technical Information Center

DOE Headquarters

R. W. Barber, Director

Nuclear Reactor and Facility

Safety Division

U.S. Department of Energy

Washington, DC 20545

L. J. Deal, Acting Director

Division of Radiological Controls

U.S. Department of Energy

Washington, DC 20545

N. Goldenberg, Acting Director

Quality Assurance

U.S. Department of Energy

Washington, DC 20545

B. L. Murphy

Health Physics

U.S. Department of Energy

Washington, DC 20545

G. K. Oerte?, Deputy Asst. Secretary for Safety, Health, and Quality Assurance

U.S. Department of Energy

washington, DC 20545

R. J. Stern, Director

Dffice of Environmental Guidance

U.S. Department of Energy

Washington, DC 20545

25 E. J. Vallario

HeaTth Physics

U.S. Department of Energy

Washington, DC 20545
No. of

Copies

M. Walker

Assistant Secretary for

Environment, Safety and Hea1th

U.S. Department of Energy

Washington, DC 20545

DOE Albuquerque Operations Office

R. E. Alexander, Safety Director Pantex Plant

Mason \& Hanger--Silas Mason Co., Inc.

P.0. Box 30020

Amaril1o, TX 79177

W. D. Burnett, Manager

Health Physics Division

DOE Sandia National Laboratories

$\mathrm{Ma}$ i] Code 3312, Bldg. 8619

P.0. Box 2800

A1buquerque, NM 87115

G. W. Campbell

Rockwe 11 Internationa 1

Rocky Flats, P.0. Box 464

Golden, CO 80401

C. E. Garcia

U.S. Department of Energy

Albuquerque Operations Office

P.0. Box 5400

A1buquerque, NM 87115

H. E. Meyer, Manager

Health Physics

Mound Laboratory

Monsanto Research Corporation

P.0. Box 32

Miamisburg, OH 45342 
No. of

Copies

P. M. Ramey

Albuquerque Operations Office

U.S. Department of Energy

P.0. Box 5400

Albuquerque, NM 87115

J. J. Thompson

Lovelace Biomedica] \& Environmental

Research Laboratories

Hea ith Protection Operations

P.0. Box 5890

A]buquerque, NM 87115

A. M. Valentine, Group Leader

Health Physics

Los Alamos National Laboratory

P.0. Box 1663

Los Alamos, NM 87545

M. G. White

U.S. Department of Energy

P.0. Box 5400

Albuquerque, NM 87115

R. E. Yoder, Director

HeaIth, Safety, and Environment

Rockwe 11 International

P.0. Box 888

Golden, C0 80401

DOE Chicago Operations Office

D. L. Bray

U.S. Department of Energy

9800 S. Cass Ave.

Argonne, IL 60439

L. V. Coutson, Head

Safety Section

Fermi Nationai Accelerator

Laboratory

P.0. Box 500

Batavia, IL 60510

E. H. Dolecek

Argonne National Laboratory

9800 S. Cass Ave., Bldg. 201

Argonne, IL 60439
No. of

Copies

C. B. Meinhold, Head

Safety \& Environmental Protection

Division

Brookhaven National Laboratory

Associated Universities, Inc.

Upton, NY 11973

R. Moser, Director

Operational \& Environmental

Safety Division

Chicago Operations Office

U.S. Oepartment of Energy

9800 S. Cass Avenue

Argonne, IL 60439

0. P. O'Neil

Argonne National Laboratory

9800 S. Cass Ave.

Argonne, IL 60439

DOE Idaho Operations Office

J. H. Barry, Director

Operational Safety Division

Idaho Operations Office

U.S. Department of Energy

550 2nd Street

Idaho Falls, ID 83401

B. J. Beers, Assistant Manager

Environmental, Safety and

Health Programs

Idaho Operations office

U.S. Department of Energy

550 2nd Street

Idaho Falls, ID 83401

T. F. Gesel1

Radiological and Environmenta?

Sciences Laboratory

U.S. Department of Energy

550 2nd Street

Idaho Falls, ID 83401

B. L. Rich

Health and Safety Division

EG\&G Idaho

P.0. Box 1625

Idaho Falls, ID 83401 
No. of

Copies

DOE Naval Reactors Office

T. L. Collins, Manager

Knolls Atomic Power Laboratory

U.S. Department of Energy

P.0. Box 1072

Schenectady, NY 12301

A. C. Davis, Manager

Bettis Atomic Power Lab.

Westinghouse Electric Corporation P.0. Box 79

West Mifflin, PA 15122

C. K. Gaddis, Manager

Pittsburgh Naval Reactors Office

P.0. Box 109

West Miffin, PA 15122

DOE Nevada Operations Office

B. W. Church

Health Physics Division

Nevada Operations Office

U.S. Department of Energy

P.0. Box 14100

Las Vegas, NV 89114

S. R. Elliot, Director

Office of Safety and Health

Nevada Operations Office

U.S. Department of Energy

P.0. Box 14100

Las Vegas, NV 89114

A. Bicker

Environmental Sciences

Department Manager

Nevada Test Site

Mercury, NV 89023

DOE Oak Ridge Operations Office

R. C. Baker

Head \& Environmental Coordinator Environmental Control Department

Paducah Gaseous Diffusion Plant

P.0. Box 1410

Paducah, KY 42001
No. of

Copies

W. F. Furth, Director

Environmental Safety and Health

Martin Marietta Energy Systems

P.0. Box $X$

Oak Ridge, TN 37831

R. E. Halliburton

Oak Ridge National Laboratory

P.0. Box $X$

Oak Ridge, TN 37830

S. L. Hinnefeld

Radiation Safety Department

Westinghouse Materials Co. of Ohio

P.0. Box 398704

Cincinnati, OH 45239

D. B. Howard

Oak Ridge Operations Office

U.S. Department of Energy

P.0. Box E

Oak Ridge, TN 37831

T. M. Jelinek, Chief

Health Protection Branch

Oak Ridge Operations Office

U.S. Department of Energy

P.0. Box E

Oak Ridge, TN 37831

W. T. Mee, Superintendent

Radiation Safety Department

$Y-12$

P.0. Box $Y$

Oak Ridge, TN 37830

D. C. Parzyck, Director

Environmental and 0ccupational

Safety Division

Oak Ridge National Laboratory

P. 0 . Box $X$

Oak Ridge, TN 37830

B. G. Roach

Health and Safety Officer

ORAU

P.0. Box 117

Oak Ridge, TN 37831 
No. of

Copies

J. Shoemaker

Health Physics \& Environmental

Affairs Division

Oak Ridge Gaseous Diffusion Plant

P.0. Box $P$

Oak Ridge, TN 37831

F. G. VanLoocke

Health, Safety and Security

Representative

RMI

P.0. Box 579

Ashtabula, OH 44004

E. Wagner

Industrial Hygiene and

Health Physics Dept.

GAT

P.0. Box 628

Piketon, $\mathrm{OH} 45661$

DOE San Francisco Operations

Office

T. R. Crites

Lawrence Livermore National

Laboratory

P.0. Box 5505

Livermore, CA 94550

J. T. Davis, Chief

Operational Safety and Compliance

San Francisco Operations Office

U.S. Department of Energy

1333 Broadway

0akTand, CA 94612

R. V. Griffith

Lawrence Livermore Nationa T

Laboratory

P.0. Box 5505

Livermore, CA 94550

W. E. Keheley, Branch Chief

Environment and Nuclear Safety

San Francisco Operations office

U.S. Department of Energy

1333 Broadway

Oakland, CA 94612
No. of

Copies

R. C. McCall, Rad. Safety Officer

Stanford Linear Accelerator

P.0. Box 4349

Stanford, CA 94305

P. Phelps

Lawrence Livermore Laboratory

P.0. Box 5505

Livermore, CA 94550

R. H. Thomas

Lawrence Berkeley National

Laboratory

University of California

Berkeley, CA 94720

A. J. Toy, Head

Hazard Control Department

Lawrence Livermore Nationa]

Laboratory

P.0. Box 80B

Livermore, CA 94550

DOE Savannah River Operations

office

D. N. Bridges

Savannah River Operations Office

U.S. Department of Energy

P.0. Box A

Aiken, SC 29801

R. M. Hall

E.I. duPont de Nemours and Co.

Savannah River PTant

Aiken, SC 29809

W. A. Reese, Director

Safety and Environmental Division

Savannah River Operations Office

U.S. Department of Energy

P.0. Box A

Aiken, SC 29801

W. C. Reinig, Superintendent

Health Protection Department

E.I. Du Pont de Nemours \& $C_{0}$.

Savannah River Plant

Aiken, SC 29809 
No. of

Copies

EPA Office of Radiation Programs

A. Richardson

Criteria \& Standards Division

AW-460

401 M Street, SW

Washington, DC 20460

National Center for Devices and Radiological Health

J. T. Lewis

Center for Dev. \& Radiol. Health

Office of Heat th Physics

HFZ-60, Rm. Chap. 332

5600 Fishers Lane

Rockville, MD 20857

J. C. Villforth, Director

FDA Bureau of Radiological Health

RockvitTe, MD 2D852

National Bureau of Standards

R. Colle'

National Bureau of Standards

Ga ithersburg, MD 20899

E. H. Eisenhower

Office of Radiation Measurement

National Bureau of Standards

Gaithersburg, MD 20899

R. Loevinger

National Bureau of Standards

Gaithersburg, MD 20899

R. B. Schwartz

Nationa 1 Bureau of Standards

Building 235

Gaithersburg, MD 20899
No. of

Copies

Nuclear Regulatory Commission

R. E. Alexander, Chief

Radiation Risk Assessments and Management Branch

Office of Nuclear Regulatory

Research

U.S. Nuclear Regulatory Commission Washington, DC 20555

A. Brodsky

U.S. Nuclear Regulatory Commission

Wilste Bldg., MS-1130 SS

7515 Eastern Ave.

SiTver Spring, MD 20912

L. K. Cohen

Office of Inspection \& Enforcement U.S. Nuclear Regulatory Commission Washington, DC 20555

L. J. Cunningham

Operating Reactor Programs Branch Division of Inspection Programs

U.S. Nuclear Regulatory Commission Washington, DC 20555

M. V. Federline

Office of Executive Director For Operation

U.S. Nuclear Regulatory Commission Washington, DC 20555

K. R. Goller

U.S. Nuclear Regulatory Commission

Div. of Rad. Prog. \& Earth

Sciences, MS-1130 SS

Washington, DC 20555

R. E. Minogue, Director

Office of Nuclear Regulatory Research

U.S. Nuclear Regulatory Commission Washington, DC 20555 
No. of

Copies

R. B. Neel

U.S. Nuclear Regulatory Commission

Wilste Bldg., MS-1130 SS

7515 Eastern Ave.

Silver Spring, MD 20912

L. C. Rouse, Chief

Advanced Fuel and Spent Fuel Licensing Branch

Division of Fuel Cycle \& Material

Safety

U.S. Nuclear Regulatory Commission

Washington, DC 20555

\section{ONSITE}

3 DOE Richland Operations Office

J. J. Sutey/P. K. Clark

R. E. Gerton

K. H. Rising

Rockwell Hanford 0perations

J. F. Albaugh

Westinghouse Hanford Company

R. 0. Budd
No. of

Copies

United Nuclear Company

W. L. Nees

48 Pacific Northwest Laboratory

W. J. Bair

L. H. Brackenbush

C. P. Brim

J. U. Denovan

F. N. Eichner

G. W. R. Endres

T. H. Essig

L. G. Faust

J. J. Fix

D. E. Hadlock

R. Harty

G. R. Hoenes

C. D. Hooker

K. L. Jones

R. L. Kathren

H. V. Larson

J. C. McDonald

W. D. Reece

P. L. Roberson (15)

J. M. Selby (5)

K. L. Swinth

R. J. Traub

Health Physics Department Library

Publishing Coordination (2)

Technical Information (5) 